\title{
TUDO O QUE É DITO, É DITO POR ALGUÉM: a noção de cidade como espaço cognitivo
}

\author{
Leandro Marino Vieira Andrade* \\ Margarete $\mathrm{AxT}^{* *}$
}

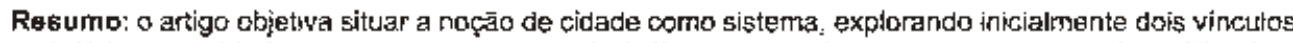

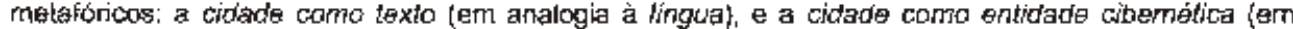
analogia a rráquinas ou organismos wivos). Desde entäo, propōese duas possibilidades teóricas de

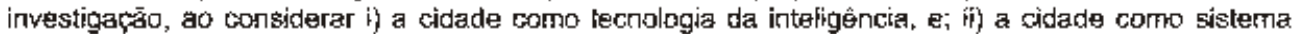
cogrifivo complexo.
\end{abstract}

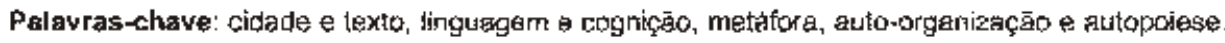

Abstract: the paper aims lo situate the notion of city as a system, exploring two metaphorle thing, at fict: the dity as text \{in analogy to the language\}, and the city as cybernetic entity (in analogy to machines or fiving organisms). Since then, it intends two theoretical possibilities of tr vestigation, when wonsibering i) the aty as technology of the intelligence, and; ij) the city as complex cogritive system.

Kay words: city and text, language and cogrition, metaphor, sett-organization? and autopoiesis.

\section{Introduçāo: metäfora como modelo}

Toda a reflexă, inclusive a reflexăo sobre os fundamentos do conhecer humano, se dá necessariamente na linguagem, que é nossa forma particular de sermos humanos e estarmos no fazer fumano. (...) Tudo o que gito e di to por alguen. Toda a reflexao produz um mundo (Maturana, varela: 1995:69).

No aforismo cunhado por Humberto Maturana e Francisco Varela - que empresto como título para este artigo, e com o qual os autores pontuam seu ponto de vista no belo livro $A$ ávore do conhecimento (1995) viștumbro a provocaçâo necessária para refletir sobre as relaçoses que conectam o campo do urbanismo ao dominio da linguagem. De outra parte, toma corpo urm segundo aforismo, este tecido por Michel de Certeau (1985:15), ao sustentar ser "fugar igual a lingua", isto e coordenando pratica sócio-espacial e linguagem, em um mesmo campo de observáveis ou, como tento mostrar, um mesmo plano cognitivo.

Nos limites deste texto, penso explorar algumas possibilidades teóricas destas relaçõas. Com isso. terko sugerir que, ao privilegiarem a figura do observador que se expressa atraves da lingua - "tudo o que é dito, é dito por alguém" (p.69) - Maturana e Varela insinuamt um espaço, náo necessariamente tratado nos linnites da geometria, mas antes caracterizado por uma plasticidade que se define pelas possibilidades da linguagem humana. Revisitando Certeau, um espaço em que práticas sócio-espaciais - particularmente, urbanas - engendram cognição e, neste sentido, equivalem aos atos lingüisticos.

Nesta perspectiva, a privilegiada experiência de participaçäo no seminário Auto-organização e Autopoiese na Perspectiva da Construçāo do Conhecimento, ditigido pela professora doutora Margarete Axt em 1999 , significou a abertura epistemológica e fez-se motivação substancial para esta reflexáo. É preciso, neste sentido, destacar duas afirmaçöes chaves para a elaboraçäo de meu ponto de vista, quando poder-se-é considerar i) as instituicotes sociais como sistemas cognitivos, er ii) as instituiçöes sociais como tecnologias infelectuais (Maraschin, Axt, 1998: 137).

Edgar Morin (1991:141) diz que "...os conceitos viajam e vale mais que viajem, sabendo que viajam. Vale mais que viajem clandestinamente. (...) Com efeito, a circulaçäo clandestina dos conceitos tem, apesar de tudo, permitido às disciplinas evitarem a asfixia $\theta$ o engarrafamento." Assim, angumento que esta viagem segue seus itinerários em meio ao "espaço" conformado pela linguagem humana. Os conceitos encontram entäo novos lugares de acoplamento, fixando residència na explicaçăo de outros fenômenos.

Por outro lado, croio importante năo chrçnscrever tais trajetórias - ora marcadas pelo acaso, ora pela intencionalidade - aos limites do saber acadénico. No amplo dominio das artes - particulanmente na literatura $e_{\text {, }}$ nos dias atuais, cada vez mais, no cinema - esse andejar das ideias seja, taivez, a essência de set movimento.

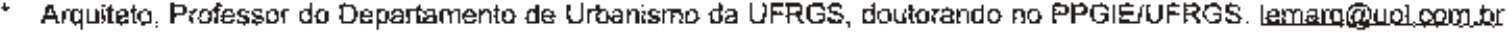

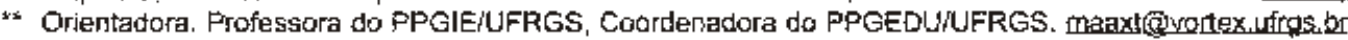


Hya Prigogine (1996a, 1996b, 1996c), responsavel por algumas das ideias revolucionárias que estäo no centro do debate sobre os rumos da ciēncia conternporânea, propondo mesmo uma nova aliança entre o homern, a natureza e o dominio das ciéncias, cita com a mesma propriedade, entre tantos eminentes nomes da fisica, como Einstein e Boltzmann, da matemática, como Poincarè, ou da biologia, como Darwin ou Schrödinger; da filosofia, desde Aristoteles até Bergson; tambérr a Valéry, a Borges ou (o que me apraz, particufarmente) a Italo Calvino.

De Calvino, Prigogine (1996:194) năo poderia deixar de referir às Cosmicomicas (1992), uma delicada fäbula contemporânea, onde um personagem de nome impronunciável, eterno e metamorfo, navega pelo tempo desde o big bang, e nos introduz, com leveza e humor, no pensamento atual sobre a origem do universo, a formaçāo das galaxxias, estrelas e planetas, o surgimento da vida... Já para um urbanista, como o autor deste ensaio, As cidades invisiveis (1991) é o livro que permanece, em constante manuselo, sobre a mesa de trabatho.

Instigante obra da literatura contemporânea, As cidades imvisiveis de Calvino dăo a conhecer uma serie de diálogos imaginários entre Marco Polo, o navegador veneziano que viveu no século XIII, e o imperador mongol Kublai Kahn. O lendário explorador, colocando-se a seviço do poderoso imperador, è encartegado de visitar as numerosas cidades do reino. Cada cidade visitada representa uma breve mas intensa alegoria simbólica, que sentåo narrada ao senhor dos mongóis. De fato, cada narrativa expressa, como metáfora, os distintos aspectos de uma "cidade real" - Veneza, ao fim da idade média - a qual Marco Polo nunca menciona diretamente.

A abra de Calvino mostrou-se fértil à reflexäo no campo da arquitetura e do urbanismo, conquanto suas cidades imaginadas passeiam com facilidade da metáfora literária ao mundo das cidades visiveis e reais. Vale citar, entre autores reconhecidamente importantes, ao argentino Rubén Pesci $(1985,1999)$, um dos nomes mais significativos da arquitetura latino-americana contemporânea, que ai encontra as iluștraçŏes para descrever o atual quadro de conflitos que emergem das grandes cidades pos-industriais; e Anne Spim (1995), onde cenários de ordem e de caos estăo referidos como imagens da cidade possivel.

Se adotamos a metáfora como velculo para o andejar dos conceitos, há também de observálla no dominio dos possiveis (Plaget, 1985,1995), isto é, em sua capacidade de atualizar-se na interpretaçăo desses novos fenômenos aos quais emprestam uma explicação. De outro modo, explica Leảo (1999:15) que a metáfora conforma uma categoria de conhecimento em que dois campos de saber interagem na constituiçäo de um terceiro, que caracteriza-se pela re-descriçăo de um determinado fenómeno.

Interessa-me, no presente trabalho, explorar a idéia do vinculo metafórico entre espaço (da cidade) e linguagem porque, como tentarei apresentar brevemente ao longo do texto, o urbanismo abraçará recorrentemente a metáfora como forma de explicar seu próprio objeto. Neste sentido, a metáfora constitui-se em modeto.

Discutirei, portanto, este fenômeno complexo - a cidade - na perspectiva de duas metáforas que constituiram, através de recorrentes manifestaçōes na literatura concemente, significativos e particulares sistemas de explicaçäo para os processos de urbanizaçāo: refiro-me à cidade como texto (em analogia à lingua), e a cidade como entidade cibernetica (em analogia às máquinas ou organismos vivos). O trabalho toma-se, então, um exercicio de leitura da cidade, à luz de uma eclética junçăo de conceitos que se avizinham através da noção de sistema, a qual pretendo contextualizar na seção seguinte.

\section{Cidade como sistema}

Uma tosca ponte de madeira transpōe um riacho. Desta forma, a estrada continua e aquele que a percorre supera o obsláculo. Se desavisado, o percorredor poderá seguir em frente, sem que a ponte ou o riacho ocupem-lhe sequer um lugar na memória. Assim, independente do conhecimento do percorredor (sobre pontes ou riachos, ou mesmo de que cruzou, em sua pressa, uma ponte sobre um riacho) a ponte terá sido soluçâo para um problema. Alguém - que charnarei de desenhador - a construil, no entanto: primeiro em sua mente a depois no lugar onde agora pemanece. Pode fazé-lo porque compreendel a essência do problema. Um outro, a contemplador, com menos pressa em seu andejar, parou sobre a ponte e demorouse em olhar ao redor. Percebeu o riacho: a água correndo em seu leito e também suas margens cobertas de mata, abrigando um mundo de vida e significado; percebeu a pante e mais: a intençäo de fazer-se porte na açăo do desenhador. Por fim: percebendo também que a madeira da mata e a madeira da ponte constituiam-se em uma mesma substáncia e essência, pode criar um mundo, onde agora coexistem os mundos do riacho, da ponte, do percorredor, do desenhador e o selu proprio, em una totalidade de acasos e intençôes (Andrade, 1999b:21)'. 
A uma ponte, pode-se construir de incontaveis maneiras, utilizando-se diferentes tecnologias e materiais diversos, conforme a especificaçăo do problema, em particular. Ao fazer uma ponte, é preciso compreender, portanto, a natureza do problema. E o que permitia ao desenthador vencer văos pequenos a grandes, conquistar riachos ou rios caudalosos, conforme seja o caso.

Cartóes postais de suas respectivas cidades, a Golden Gate, em Săo Francisoo, a travessią Regis Bitencount, em Porto Alegre, são, tomando esse ponto de vista, tăo pontes como aquela feita de madeira tosca. A primeira vale-se da compreensão profunda da distribuiçāo das tensōes dinâmicas ao longo de cabos que definem sua estrutura suspensa. A segunda exige compreender o processo complexo de tensão, compressão e cizalhamento dos materiais, para equalizar as forças que tendem a romper poderosos pilares de concreto. A natureza viva, em nosso entomo, opera os mesmos principios: ha teia de uma aranha, de um lado; no tronco de uma arvore, de outro, por exemplo.

A Ponte Vecchio, em Florença, ligando os Uffizi até o Palazzo Pitti, com lojas e habitaçōes agregadas à estrutura aporticada original, é uma ponte (isto é pertence à classe ponte) e é tambem cidade: ravela um padrăo de orģanizaçāo próprio do urbano. Ponte, casas e lojas, em sua inusitada construçăo no espaço no tempo de Florença, conformam uma construçăo de tal forma integrada, cujos acoplamentos - partes e todo tornam sem sentido separar ponte de cidade.

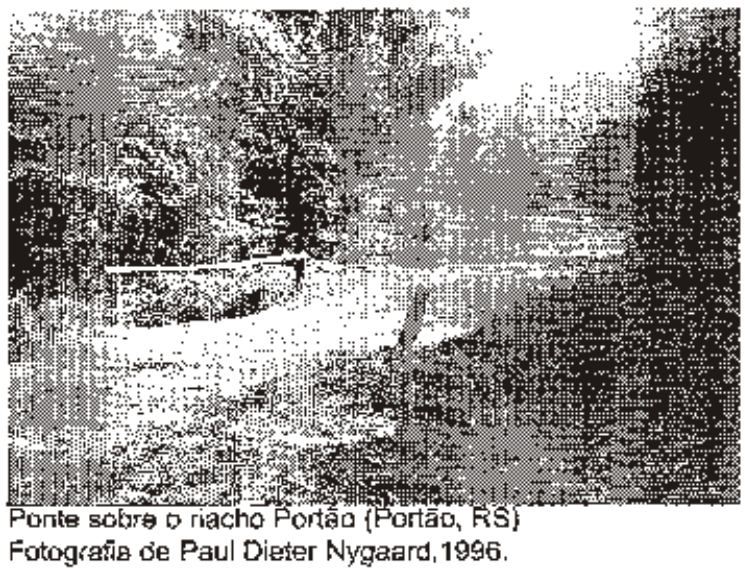

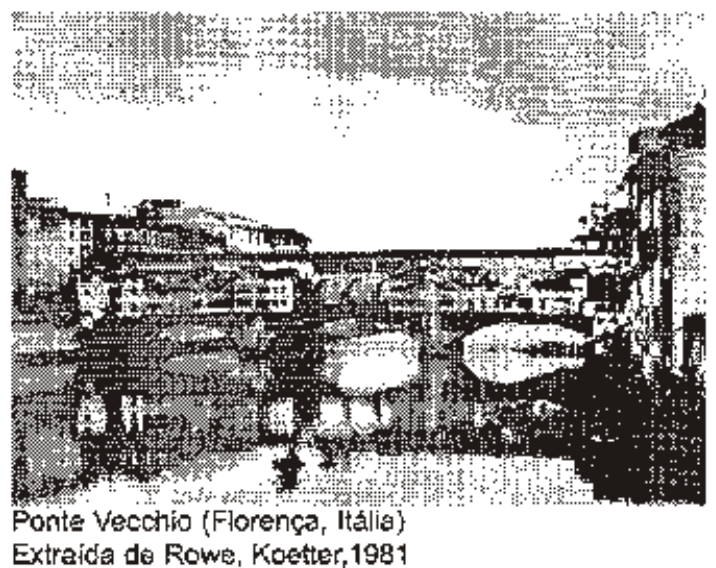

Extraida de Rowe, Koetter, 198 1

Um padräo, na definição de Alexander (1981,1982), relaciona problema e inumeráveis possibilidades de soluçäo, ao encerrar a essência de uma qualidade sem nome - expressâo que o autor utiliza para amalgamar uma multidăo de outras qualidades que, tomadas isoladamente, seriam insuficientes para descrever a complexidade dessa telaçäo - de tal forma que, quando o compreendemos, temos entzo a resposta para uria classe de problemas: aqueles que se apresentem análogos ou variantes do problema originalmento examinado. Um padtá pressupöe um imperativo empirico (Alexander, 1978:66), isto é, um problema real, mas const. tui-se cognitivamente numa estrutura do pensamento, que coordena as componentes do problema e suas relaçöes em um conjunto de possibilidades projetuais. Neste sentido, a noçáo de padráo taz do percorredor, do desenthador e do contemplador, um úniço sujeito cognitivo.

Piaget revels esse conthecer quando sugere distinçoes entrelaços no fazere no compreender (1978), e quando explora o dominio dos possiveis (1995), ou seja, aquilo que do mundo, o sujeito deve atualizar. Maturana e varela (1995:83) examinam uma cadeira, para demonstrar a organização que pertrite definir uma classe que reúne todas as cadeiras possiveis. Na literatura, Calvino (1991:67), emprestando a voz do impera. dor Kublai Khan, preceitua um modelo de cidade da qual extrair todos as cidades possiveis. Assim, dessas diferentes perspectivas, transparece uma interface epistemológica em que a noçäo de sistema subjaz como modelo, isto é, ela própria um sistema de explicaçäo (Braudel, 1991:58).

Ao introduzir a noçăo de sistema, é prudente definjila mais propriamente. Sistemas são "complexos de elementos em interaçäo (Bertalanffy: 1977.56)", ou, em poucas palavras, conjuntos de "coisas" que operam em algum grau de solidariedade, de forma que o que sucede com cada parte traz conseqüencias para a totalidade, e vice-versa, Outro aspecto a considerar é que as características do todo não podem, necessariamente, ser explicadas do conhecimento dos elementos isolados. Partes e relaçoes entre partes - isto e, uma estrutura conotam, numa abordagem sistēmica, um padrāo de organizaçāo. Com relação a estrutura e organizaçăo, dois conceitos chaves para compreender a noçăo de sistema, tomemos o que dizem Mațrana e varela: 
Entende-se por organizaçāo as relaçōes que dewem şe dar entre os componentes de um sistema para que este seja reconhecido cono membro de uma classe especifica. Entende-se por estrutura os componentes e as relaçỏes que concretamente constituen uma determinada unidade e realizam sua organízạ̧āo (1995:87).

A noça de sistema - atualizada como sistema urbano - permite visualizar então, uma relação - um conjunto de relaçóes - que enlaça, no espaço da cidade, comunidade e tertitório. Essa relaçăo, de alguma

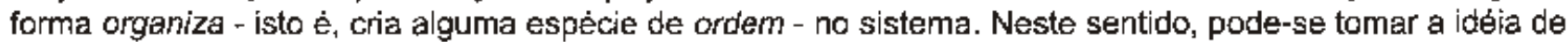
totalidade como uma qualidade emergente dos sistemas urbanos, através da coordenaçāo de partes, quando parece haver consistência em considerar as noçöes de auto-organização e autopoiese como explicativas, em alguma medida, às coordenaçōes estruturais que dăo forma, vitalidade e sentidơ às cidades.

Como auto-organizaçá, entende-se a possibilidade de, no interior de sistemas tonge do equillbrio, emergirem paralelamente condiçōes de desordem e ordem dinâmica (Prigogine, 1984,1996; Prigogine e Stengers ${ }_{r}$ 1996; Attan, 1992). Em todo caso, interessa aqui compreender essa possibilidade no que tange aos sistemas humanos e sociais, tomando tal perspectiva em extensẫo, no sentido da conformação de estruturas sócio-cognitivas em rede, no seio da cidade, capazes de alavancar transformaçōes que operem sobre todo o sistema (como no caso dos movimentos sociajs, por exemplo).

A autopoiese (Maturana e Varela, 1995,1997), constitui-se em um processo imanente às estruturas com características cibernéticas (portanto "máquinas"), com capacidade de produzirem a si mesmas. Mais precisamente:

Uma máquina autopoiética é uma máquina organizada como um sistema de processos de produçăo de componentes concatenados de tai maneira que produzem componentes que: I) geram os processos (relaçöes de produção que os produzen através de suas continuas interaçöes e transformações, e ll) constituem a máqujina no espaço fisico (Maturana e varela,1997:71).

Os autores da teoria da autopoiese, como explicação dos sistemas viventes enquanto estruturas homeostáticas que se auto-organizarm e auto-produzem, mantêm-se céticos quanto às possibilidades de generalizaçăo do conceito, para alérn do contexto biológico no qual foi cunhado. Luhmann $(1997)$, entretanto, absorve esta perspectiva para propor uma teoria sistêrnica da sociedade, que considera como rede autopoiática de comunicação.

Especulativamente, poder-se-ia propor a condiçăo autopoiética do unbano, se compreendida no plano de coordenaçöes sucessivas (Maturana,1999), configurando um sistema autopoiético de terceira ou mais alta ordem. Por exemplo coordenaçōes (na constituição de lugares) de coordenaçōes (de interesses de grupos sociais e forças econômicas) de coordenaçōes (de sujeitos).

Num certo sentido, Christopher Alexander reflete sobre as condiçóes auto-organizadora e autopoiética no espaço urbano, quando sugere uma teorla geral onde a abordagem sistémića percorre um longa trajetória conceitual que inicia-se nas formulaçōes primordiais do campo da cibernética (Alexander, 1997) até consolidar uma abordagem que trata os sistemas de organizaçāo espaciais arquitetónicos e urbanos, como parte indissociável da propria condiçáa humana (Alexander, Neis, Anninou, King,1987). O conceito central dessa teoria pode ser traduzido pela idéia de um processo de crescimento integral do conjunto (ou da totalidade: growing whole, no original), através de elementos que Alexander chamará de centros. A noção de totalidade (wholeness) se alicerça em algumas propriedades intrinsecas ao seu própro processo de produçáo de centros, isto é, caracterizam o processo e năo estritamente os seus resultados, aproximando-se de uma defiriç̧ăo autopoietica.

A cidade é, talvez, a mäis complexa invenção humana, conformando o locus genético da criatividade e do conhecimento, das tecnologias, dos comportamentos, dos valores e das contradiçóes da experiéncia humana. $O$ enfoque sistèmico conduz a um ohar atencioso sobre as possibilidades teóricas das noçóes de autoorganizaçåo e autopoiese no domínio da cidade. As seçöes seguintes ocupam-se em examinar duas das visōes metafóricas da cidade - em ponderável medida, dominantes na construção do pensamento urbanístico - no sentido de seguir trilhando as trajetórias conceituais acima esboçadas.

\section{Cidade como texto / espaço urbano como ato lingüístico}

Talvez a mais sedutora das metäforas, aquela que equipara cidade e texto em um mesmo domínio cognitivo, tem sido uma poderosa motivação ao campo da análise arquitetōnica e urbanistica. Da lingüistica,, s 
arquitetos tomamos, entre outras apropriaçós mais ou menos "clendestinas", a noção de estrutura, a perspectiva analítice da morfologia e da sintaxe, a condição semåntica da arquitetura como produtora de significados, etc. Assim, na precisăo de Umberto Eco (1976), "(...) a arquitetura funciona porque comunica."

No que diz respeito ao campo das teorias arquitetônicas e urbanisticas, aceita-se que a detimitaçēo do objeto aconteça de diferentes formas, seja atraves de entogues disciplinares mais ou menos autônomios (a história, a técnica, a estética, por exemplo), søja a partir da escala espacial de interesse na delimitaçăo do problema: da escala do edificio à escala das relaçōes que se estabelecem entre um conjunto de espaços arquifetónicos, ou seja, em ưltima instância, a cidade.

Stephen Cerr (1967) afirma, em relaçāo ąo ambiente da cidade, que a construçäo de significados 6 resultado da experiencia. A cidade, neste sentido, comunica através da experiéncia de fruiçäo espacial, ou seja, um ato de posse, ou apreensảo, do /ugar. Cerasi (1977) situa esta problemática en termos de interrelação entre percepçăo e experienciaçào, entre espaço topologico e espaço psicologico, entre o meio físico e as individuas ou grupos sociais. Apoiado em Cerasi, Castello (1986) define esta diadética:

A cidade (o ambiente) compreende fatos fisicos (os espaços arquitetónicos, os aspaços abertos, os espaços naturais modificados) f fatos comportamentais (o uso que grupos de individuos fazen desses espaços). Há na cidade, um espaço topológico, ao qual se integra um espaço psicologico (...). (Castello, 1986;67)

Michel de Certeatu (1985), como vimos, põe em evidância a noção de atos de prática de lugar. operaçōes cognitivas de apropriaçăo do espaço, traduziveis em valores culturalmente sensiveis. Neste sentido, compara lugar à lingua, que passa a fazer sentido ho ato da fala, no spesch act do lugar.

Assim, espaço e sociedade operarn dialeticamente: a casa se torna morada no ato de morar; o mercado vivifica no ato da troca; a praça e o largo, no ato do encontro. O lugar deixa de ser apenas espaço para se tomar edficio, bairro, ou cidade, através do sentido que lhe é conferido pelas "artes do fazer" (Castello, Andrade, 1998 )

Gusberg (1986), a seu modo. compreende que a "(..) a arte e a arquitetura constituem sendas $e$ manifestaçōes semioticas"(p.21). Para o autor, a percepçäo acontece de forma seletiva, em uma relaçäo onde

(...) o homem percebe seu entomo o decodfica, ou seja interpreta-o e concebe-o como entomo falante, corno um constructo (ou produto construtivo) que o enfrenta (-...). Capta assim a espessura sigrificante de prática arquitetural como produtor de sentidos nowos (p.29).

Ao seguir-se com a analogia, o fazer arquitetónico e urbanistico completa-se como ato lingúístico. A cidade se faz fexto, na perspectiva em que o sujeito que frui, percebe experimenta o espaço urbano, näo 6 necessariamente aquele que o constrói materialmente. Ou, em outras palavras, "...os discursos podem ser separados das circunstancias em que foram produzidos (Lèvy, 1993:89)"

A feoria da arquitetura (Stroeter,1986; Krüger,1983, por exemplo) entende que, em resposta a um problema de constituição dos espaços arquitetônicos e urbanos, as funçōes utilitária e simbólica são objetos de representação, ou seja, sāo "escritas" a partir de certas analogias em relaçäo às técnicas de consirução existentes, à distribuiçäo funcional de um programa de necessidades a ser atendido pelo projeto, e às referèncias sócio-históricas que, de certa maneira, legitimam o projeto ao contexto. Como coloca Rossi, "...analogias não só existem dentro da disciplina da arquitetura, mas säo também a essência do seu significado"t. A cidade (feita de múltiplas coordenações entre sujeitos e lugares) vaj entäo compreendida como uma coleção de analogias, às quais cabe aos sujeitos definit uma taxe, e sobre a qual estes percebem e constroem, cognitivamente, uma relação pragmática.

Por outro lado, essa proximidade entre o campo teórico da arquitetura e da cidade e o domínio da lingüistica, pemite-me aqui especular quanto a possibilidade de atualizaçāo teórica da metáfora cidade/tøxto. Tomemos de Pierre Lévy (1995:88) a seguinte afirmaçăo:

Os senhores dos primeiros Estados inscreviam sua nova potenvia sobre o solo, erigindo os muros das cidades e dos templos. Esta fixaço no espaço e uma garantia de durabilidade, anuncia o firm de um certo dewir sem marcas, o declinio do tempo nomade. Reduphcando a inscriçäo urbana, a escrita pereniza sobre o granito dos santuários ou o mérmore das estelas as palawas dos padres e dos reis, suas leis, as narrativas de seus grandes feitos, as façntass de seus deuses. A pedra fala sempre, inalterável, repetindo inçansawelmente a lei ou a namativa, retomando textualmente as pajavras inscritas, como se a rei ou o padre estivessem lá en pessoa para sermpre. 
Antes mesmo da invença da escrita, no circulo dos consehos dos chăs, em tempos muito antigos, a palawra inicjawa a perpetuar-se petas próticas orais, consituindo, pelas conduras culturais (Maturana e Varela, $1995: 226$; os domínios do linguajar. Do clrculo das tribos imemoriais ao espaço da praça, coordenarnse praticas sócio-espaciais que relacionam o dominio lingúistico a um nascente modo de vida urbano. Para Krier (1978:18), a praça é a primeira criaçáo humana como construçäo ubana, constituindo o espaço gregário, de encontro, comércio e interação cultural. Desde a praça, as ruas partem para domesticar o territorio da cidede. Acesso a praca significa pertencer ao novo mundo utbano. $O$ chculo tornado praca, marca também 0 petio das mesquitas, castelos e mosteiros, espaço que é cuore na constituiça das coordenç̧oses entre os sujeltos de uma comunidade. Como lugaf sócio-cognitiva, a cidade conforma, desde suas origens, uma dinâmica rede semántica, com rebatimento topológico e psicológico.

Lévy reconstitui a história das tecnologias da intelgència, integrando o programa para uma ecologia cognitiva, a questấo das tecrologias digitais, particularmente em suas possibilidades na conformaça de inteligéncias coletivas, a configurar um novo e ampliado domínio sócio-cognitivo, definido no ciberespaço. Nesse itinerário, disçute desde a linguagem oral, a invançăo da escrita, da imprensa e da comunicaçăo por rádio o teletonia, para entäo situar as possibiljdades de inferaço tolemática como um novo patamar de conthecimento, no plano das tecnologias da inteligéncia.

Assim, o autor formula um conceito mais preciso à jobia de hipertexto apresentando-o como rede semântica, caracterizada por seis princípios nomativos: ij a metamofose, isto é, uma constante construçāo, renegociaçāo e redefiniçẩo dos atores; ii) a heterogeneidade referida aos nós e conexốes da rede semántica: modelos, imagens, palawras, etc. em coordenaçăo com conexöes logicas, intultivas, afetivas, etc; i iij) a multiplicidade e o encaixe da escalas, organizando o hipertexto em um modo fracta\}, o seja, cada conexäo ou nó podendo revelar, em si mesmo, uma nova rede semantica; iv) a exterioridade (dos atores), na ausência de uma "unidade orgànica" ou de autonomia da rede semantica; v) a topologia, atraves da possibitidade de relaçōes antre caminhos, conquanto ". . a rede nāo esta no espaço, ela é o espaço." (p. 26), é iv') a mobilifade dos centros, ho sentido da inexistencia de um único centro organizador, mas sim de uma rfultiplicidade de centros que estão em constante rearranjo.

Em cada um destes princlpios, é possivel reconhecer e atualizar a metáfora do texto em hipertexto urbano. Nesta perspectiva, ao modo da espẹulaçăo que este texto pretende suscitar, se a cidade conporta-se como uma estrutura que se auto-orgariza de maneira hipertoxtual, as mesmas qualidades apontadas por Lévy podem ser, como hipótese, visłumbradas no sentido da cidade. Tómando algumas colocaçoes, primeiramente lançadas no artigo Explorando Santa Fé (Andrade e Axt, 1999b):

a) Em relação à noção de metamorfose, o processo de constituçāo histonica da cidade enseja um conjunto de escolhas e relaçós analógicas que conconem na emergencia de totalidades de lugares, em uma coordenaçăo de múltiplas escalas. Com relaçäo aos agentes - os que constroem materiaimente, os que percebem o espaço, os que expenmentam os recintos unbanos arquitetónicos - estes dividem (e interggem con) um dominio hipertextual. A praça central do uma cidade qualquer, ora menado, ora esplanada civica, ou anda lugar do fortuito encontro cotidiano, säo exemplos dessa multiplicidode semäntica.

b) Em relaçăo à ideia de heterogeneidade, esta remete a uma necessária composição de diversos e diferentes requisitos funcionais e distributivos, do funcionamento harmonico dos variados sistemas e componentes (redes de circulagăo e infra-estrutura, interfaces e espacos abetos, frocessos produtivos e praticas sócio-culfurais, inter-relaçäo entre os dominios público e privado, urbs, civitas, polis). Uma cidade, e cada cidade, revela apenas utha entre as muitas oidades posslveis.

c) O principio de multiplicidade e de encaixe de escalas, por sua vez, está no centro do processo que constitui cidades. A cidade deve ser compreendida como processo no ambito conjunto de relaçóes no espaco, resultado da interaça, ou resposta, de uma rede sociotéchica. A cidade, sua arquitetura e sua organizaçăo social, é, neste sentido, sempre una construgào multi-escala.

d) O problema da exterioridade remele, a sua vez, a uma das questöes epistemologicas mais fascinantes da arquitetura e do urbanismo, e que diz respeito a sua autonomia/heteronomia em relação as redes sociotecnicas a ambientais que the dé supotte e comtexto. Se, tomando a afirmaça de Lévy. '. o senfido se constroi no contexto, e sempre local, dado, transitório. (podendo-se falar em um jogo da interpretaçăo e da construçáo da realidade" (1993:22-3), a significaçáo da cidade, como rede semantica, supöe relaçóes heterónomas entre os atores que produzem e fruem o espaco adaptado ao modo de vida unbana. 
e) A questāo da topologia pode ser referida pelo agenciamento dos espaços e das relaçóes entre espaços. Na cidade, existe uma relaçào de necessária proximidade entre atividades que se complementam: o mercado e as instituççes civicas, por examplo. Um conjunto de residencias pressupóe uma relação de vizinhança. Entre a casa e a ria, existe um intervalo (Hertzberger, 1996:32-9) - uma especie de "conexżo hipertextual" - de mudança de escala e dominio.

f) Por fim, a mobilidade de centros, em relaçäo ao problema da cidade, pode ser reconhecida na noçāo de speech act (Certeau, 1985), ato lingüisfico que se realiza na interaçāo social, da família ou do individuo, entre sujeito e lugar. As tipologias arquitetônicas, em centa medida, aprisionam essas relaçöes essenciais. A arquifetura vernacular do sul da Argentina fomece um itinerário interessante de ser compreendido, na ralaça entre casa e cidade. A casa platense tipica, por exemplo, conectase à rua através de um saguăo configurado por um antecalmara com uma porta extema - sempre aberta, que convida a entrar - e uma intema - cerrada, que confere ao dono da casa, a prerrogativa de aceitar ou não a presença do visitante nos recintos interiores da morada. Da mesma forma, a plano da fachada, coincidente a linha municipal, estabelece um espaço urbano positivo (Alexander, 1987) que normaliza esses deslocamentos.

\section{Espaço urbano como norma / eidade como entidade cibernética}

Lynch (1985), ao se debruçar sobre o estudo das teorias gerais normativas da forma urbana - ou seja, teorias fundadas em um conjunto coerente de pressupostos, de forma a justificar determinada configuraçäo espacial - define trés amplas categorias, marcadamente metafóricas, como ponto de partida para uma classificaçăo das abordagens que pretendem-se integrais à complexidade urbana. Assim, apresenta um panorama das cidades de inspiraçăo cósmica (pp.6f-67), das cidades vistas como máquinas (pp.67-70) e das cidades interpretadas como organismos whos (pp . $7 \uparrow-78$ ). Tomando esta perspectiva, parece-me consistente considetar as três mefaforas normativas dentro de um mesmo plano conceitual, qual seja o da cidade compreendida como uma entidade cibernética.

Como se sabe, a cibemética conforma uma abordagem cientifica que, antes de constituir-se como disciplina, preceitua noççes cuja validade pode, em certa medida, alcançar diferentes dominios do conhecimento. Neste sentido, considera fortemente a noçäo de sistema, na interpretação dos arranjos funcionais, considerados mecanismos, seja de máquinas concebidas pelo homem, seja quando seus preceitos são aplicados a organismos naturais. De fato, a denominação deriva da palavra grega Kiber - significando, timoneiro - e se define, em seus primórdios como "ciencia do controle $\theta$ da comunicaçâ, no animal ou na máquina (Ashby, 1970:1)".

Nesta perspectiva, a cibemética tenta configurar um domínio comum, capaz de desvendar o comportamento de "todas as máquinas possiveis" - considere-se, portanto. uma maquina eletrónica, mecanica, neural ou econônica - "...e ten interesse apenas secundeno em saber se algumas delas nào foram ainda construídas, quer pelo homem, quer pela Natureza (Ashby 1970:2)". Fica evidente a emergència da idéia de sistema como noçăo chave, que fixa os limites do dominio cibemético:

A cibernética pode, de fato, ser definida como o estudo de sistemas abertos à energia, mas fechados a informaçäo a controle - sistemas que sāo "impermeàvis à informaçăo" (information-tight) (Ashby, 1970:4)

É justamente a dimensāo de controle, no sentido de uma "arte do comando", que é posta em evidencia nos primeiros esforços téricos dos ciberneticistas (Ashby, 1970:1), a condiçăo que permite, no âmbito desta reflexäo, considerar as trés metáforas dentro de um mesmo plano, este entendido como o do estabelecimento de estruturas de controle normativo, operando sobre o comportamento das relações entre sociedade espaço, caracterizáveis na perspectiva dos três modelos apontados.

\section{4.t. A cidade cósmica}

As cidades cósmices, na compreensão de Lynch, estão definidas no sentido dos assentamentos humanos cuja motivaçäo mágica - particularmente de cunho espiritual - fundou estruturas de poder, no plano social, configurando um idéário regulador do espaço topológico. Neste sentido, Lynch oferece uma fascinante leitura espacial de alguns dos processos civilizatórios dominantes na história humana, e sāo de grande interesse ao estudo das teorias urbanas, particularmente, suas descriçōes das teorias chinesa e hindu de ocupação e urbanização do terriłório. 


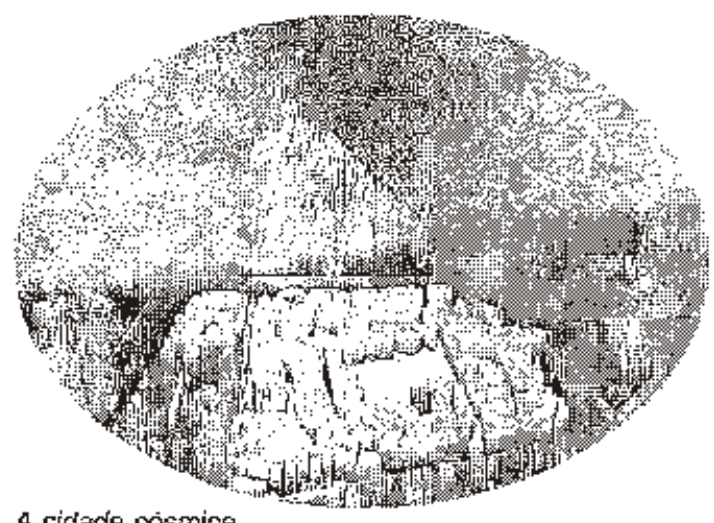

A cidade posmica.

Ilustraçäo do autor, 1997.
A teoria chinesa de configuração de cidades é fortemente fundarnentada na geomancia, como arte (ou ciència) da interpretação dos sinais da natureza. Assim, as decisōes de localizaçăo e da implantaçăo dos assentamentos humanos sāo resultantes da deliberaçäo de sacerdotes que desempenham a papel de sábios geomantes. A esses membros da estrutura de poder é delegado, portanto, o controle sobre decisōes que afetavam a sociedade como um todo.

Por outro lado, é importante enfatizar seu papel de observadores, e do sentido de uma acurada e sistemática observação dos ciclos ambientais, na construção de um conhecimento empirico - o comportamento da natureza - tomado mágico pela autoridade que thes outorgavam prlncipes a

imperadores. As decisöes baseadas na observaçäo da natureza, somavam-se uma série coordenada de rituais de fundaçāo e manutençăo das cidades. Como aparece no Li-Chi, Registro dos Rituais, datado do século I a.C.: "os ritos evitam a desordem tal como os diques evitam a inundação (Lynch, 1985:62)".

No plano da morfologia urbana, as cidades de orientação chinesa configuravam-se como uma seqüência articulada de reticulas de gräo cada vez menor - como coloca Lynch, "caixas dentro de caixas" (p.61) tomando a forma de uma gretha hierácquica. A hierarquia espacial servia de suporte fisico para a hiorarquia dos poderes político e religioso, de distribuição de incumbēncias e atribuiçōes de controle por parte dos ímperadores. O espaço da cidade, dorninado pelo grande palácio, dividia-se em simetria, à direita e a esquerda, como manifestação construída da organização do governo. Muros, portais e acessos eram consagrados às funçōes mágicas de proteçäo. Cores eram associadas aos pontos cardeais. O norte deveria ser conformado como baluarte de dofesa, tanto ao impeto da natureza, quanto à ameaça mongol.

Por outra forma, as cidades hindus mostravam sinais de uma organização ainda mais voltada ao cumprimento de ritos vinculados a religiáo. Toda a cidade - e mais, a maneira de comportar-se na cidade - era consagrada a um sern número de divindades. Os construtores de cidades baseavam suas decisóes em uma série de textos voltados para o planejamento dos assentamentos, denominados Silpasästras (Lynch, 1985:63).

Geometricamente, a teoria hindu fundava-se em um modelo na forma de mandala - representaçāo de um universo perfeito - com uma série de anéis concêntricos que organizava um tabuleiro de setores quadrados, de dimensöes crescentes, da periferia para o centro, onde localizavam-se os dominios de Brahma, como divindade suprema. Todo o território urbano é consagrado, podendo ser habitado desde que cumpridos os rituais e as divisóes parcelárias preconizados nos Silpasästras, voltadas ao controle da desordem social e espacial. Os movimentos processionais seguem a estrutura anelar, ent um sentido horário, conformando una espécie de caminho espiral da periferia para o centro, e o acesso aos anéis interiores é sempre restrito às castas hierarquicamente superiores.

Tanto no caso da teoria chinesa, quanto na hindu, a estruturaçăo espacial revela uma organizaçąo social e religiosa segregadora, através de recintos controlados, seja por funcionários govemamentais (no caso da cidade chinesa), seja implicitamente pelos deuses (como no caso da cidade hindu). Nos dois casos, as estruturas hierärquicas dos poderes divino e terreno configuram uma relaçäo de móltiplas escalas, reproduzindo compartimentaçōes, em urn desenvolvimento que poder-se-ia chamar de fractal. De maior para o menor, na cidade chinesa; do menor ao maior: na cidade hindu.

Por último, quero ressaltar a condição simbólica, em torno da relaçāo entre homens e deuses em coexistência harmónica, que dá unidade à teoria, no sentido de interpretar e conceber a cidade como uma representação da perfeição do cosmos. Nesta perspectiva, subjaz o entendirnento de que as ciđades cou ainda, as sociedades humanas), constituem sistemas de totalidades, inseridos em totalidades ainda mais complexas. Por outro lado, a busca de uma representaçäo de um universo em equilíbrio - os rituais a afastar a ameaça de desordem e a reverenciar a ordem divina - pöe a mostra a condiçăo determinista, hierarquicamente subordinada, actotada pelos desenhadores urbanos chineses e hindus. 


\subsection{A cidade coma máquina}

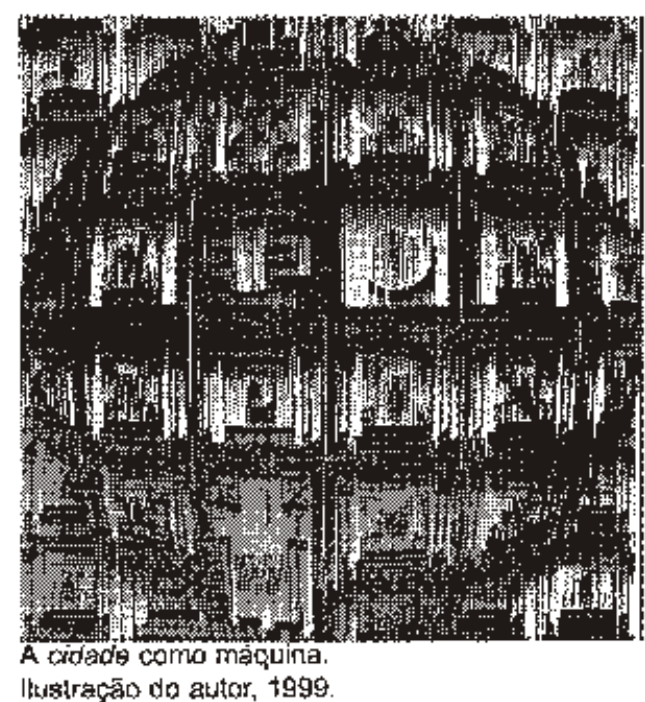

A segunda categoria concernente às teorias nomativas interpreta a cidade como uma máquina, em um sentido que coloca en evidência, de um lado, a presença de um conjunto de partes que, associadas, confomam uma estrutura estável; e de outro, uma estrutura de controle cujo objetivo é fazer funcionar as partes, para garantir eficiência ao todo. Nesta perspectiva, Lynch define o caráfer mecanicista de uma cidade assim construida:

\begin{abstract}
Uma máquina (...j tem partes permanentes: que se movem e movern as demais. A máquina inteira pode transformar-se, ainda que ofaça de forma claramente previsivel, como se movendo ininteruptamente por uma pista determinada. A estabilidade é inerente as partes e rāo ao todo. As partes säo pequenas, bem definidas, com freqüencia similares entre si, e estäa mecanicamente conectedas. (..) Nago tem um significado mas amplo: e somente a soma de suas partes. Pode decompor-se, volter a conslituir-se, inverter-se, se podem recolocar as peças e voltara a funcionar, E fatual, funcionad, "frì", nada magica. As partes să autōnomas exceto pelas instruçōes oue lines foram prescritas. Faz apenas o que faz e nada mais (Lynch, 1985:67)
\end{abstract}

Ainda que a imagem associada à idéia de máquina possa erroneamente levar à interpretação de um artefato moderno e complexo, a perspectiva teórica de Lynch procura demonstrar que, de fato, a concepção da cidade como uma máquina eficiente é quase tảo antiga quanto a cidade da ordem cosmica. Lynch observa nas cidades coloniais dos gregos, nos acampamentos militares romanos e, retrocedendo ainda mais no tempo, na configuraçäo da cidade egipcia de Kahun, voltaca a abrigar os trabalhadores que construltram a pirámide de Illahun (por volta de 3.000 a.C.), as características primordiais desse modelo feórico: a condiçäo de empreen* dimento planejado, a geometria simples e quase sempre regular, a possibitidade de construçå rapida, os espaços de controle e a separação de funçŏes elou de classes sociais (p.68).

Da marcaçăo inaugural dos acampamentos romanos - dois eixos ortogonais, cardo e decumanus, que se cruzam, estabelecendo quatro acessos simétricos, em uma planta quadrada regular, ao ubanisno contemporâneo, vale cittar uma tradiçäo continuada - e aparentemente presente, com o mesmo vigor, em diferentes culturas - de fazer cidades marcadas pelas mesmas caracteristicas de reproduçăo mecánica e veloz de partes associadas a uma estrutura espacial simples e eficaz.

As Leis das Indias, proclamadas pelos reis de Espanha em 1573, conjunto de regulamentaçỏes dirigidas a ocupaçăo territorial e urbana do novo mundo, constituiram-se como modelo ordenador e formador de cidades, definindo desde a seleção dos sítios mais adequados até a localizaçáo dos edificios públicos, o traçado em grełha ortogonak, a disposição de murahas, o parcelamento fundiário, seja na cidade, seja no campo circundante, e, inclusive o caráter de uniformidade tipológica das edificaçčes. Esse conjunto de regulamentos visava, antes de tudo, garantir a rápida posse e ocupaçăo dos novos territórios coloniais, de maneira eficiente e rápida.

O unbanismo moderno, particularmente em sua prática hegemônica entre as décadas de vinte e setenta deste seculo, atualizou, em multiplas correntes e modelos espaciais, a metáfora da máquina, adotando, quase invariavelmente, a égide da racionalidade funcional e da conformaçäo geométrica das relaçōes das partes (intercambiáveis, especializadas, e rapidamente reproduziveis e acoplàveis à estutura) e de seu conjunto dinâmico. Agrupados sob a denominação de progressistas, cunhada por Françoise Choay (1979), esse urbanismo de cunho racionalista teve origem nas formulaçóes teoricas (eventualmente praticadas) de reformadores utópicos como, entre outros, Fourier - e sua idéia de organização social denominada falansterio - e Richardson - médico inglês que, ao final do século XIX, deu a conhecer sua utopia sanitaria, a cidade idealizada de Hygeia.

A nova metáfora da méquina, matizada pela racionalidade cientifica, conduz ainda, a modelos paradigmáticos como a cidade linear, de Arturo Soria y Mata, que aproveitava-se das novas facilidades do transporte ferroviário para propor uma urbanizaçāo que podia estender-se infinitamente, estruturada ao lango de uma linha ferrea. E, principaimente, a Cidade Radiosa (1925), projeto do arquiteto franco-suiço Le Corbusier, substancial inspirador do moderno planejamento urbano, e do qual Brasilia, projetada por Lucio Costa, \& nossa mais proverbial herança. Nos anos sessenta e setenta, no movimento mega-estruturalista, com destaque para 
os projetos do grupo Archigram, a metafora da cidade como máquina segue, agora figurativamente explicita. associada a uma instigante pesquisa format e às novas tecnologias construtivas.

Lynch (1985) apresenta a estabilidade da máquina como inerente às partes, sencto o todo apenas resultado de sua soma, o que estaria em princlpio em contradiça com uma perspectiva sistêtrica. Mas quero insistir em apontar no caráter máquina, esta condiçăo de controte e de arrarjo funcional - em um certo sentido, um fechamento intormacional - que caracterizam o objeto cibernético. De fato, desde o modelo maquinistico clássico, da cidade de caracteristicas de colonização, à cidade da racionalidade expliçita e da inovaçå tecnologica, a imagem da cidade como máquina cibernética ganha força. Como o proprio Lynch coloca, a idéia de máquina parece estar na base dos enfoques hoje hegemónicos no pensamento ubanistico e na pratica do planejamento urbano, seja em mecanismos de parcelamento e ocupaçâo do solo em estratégias de controle do crescimento através de zonas nos codigos de instalaçöes e construção, ou ainda no ordenamento do trafego (p.70).

\subsection{A cidade como organismo vivo}

Diferente das metáforas que interprefam a cidade como representaçå cósmica ou organizaçāo "maquinistica", a concepç̇o da cidade ao modo de um organismo vivo surge associada a um modelo projetual de cidade, fazendo-se constituir ao passo dos desenvolvimentos da biologia, ao longo dos séculos XVIil e XIX (Lynch, 1985:72).

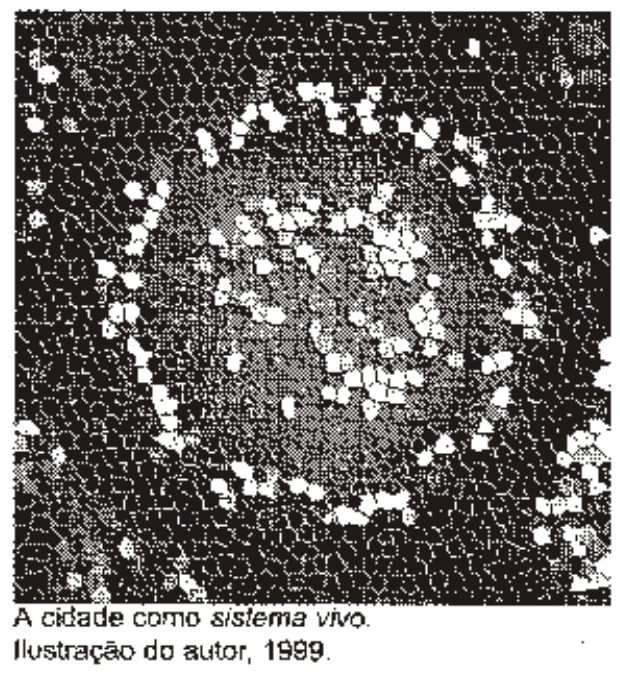

De fato, a analogia entre ofuncionamento e a forma da cidade com os sistemas vivos assinala uma reaçăo ideológica frente ì cidade congestionada e insalybre, que 6 herança da primeira revoluçäo industrial. Tal como no caso da metäfora com a máçuina, é substancial a influência do pensamento dos reformadores utópicos na formulação de um modelo urbanístico que encontra, na cidede-jardim idealizada pelo socialista inglés Ebenezer Howard - datada do final do seculo XIX e tomada realidade nos primeiros anos do século $X X$ - sua fomtlação ideal. Pouco conhecido, mesmo entre os urbanistas, é o fato de que o modelo da cidade-jardim, com sua mofologia que procurava conciliar cidade e campo, através de uma leitura arquitetònica da construção inglesa tradicional, fora concebida como parte de um organismo maior - que Howard denominou cidade social - e cuja lógica pressupunha uma ampla organizaçāo do territónio a partir de uma noçăo de crescimento cellutar controlado.

Por outro tado, a metáfora orgănica reflete, também, uma postura nova frente ao conthecimento da cidade que, acompanhando o desenvolvimento cientifico desse petiodo, e por obra de eminentes pensadores dos processos de urbanizaçăo (em particular, no contexto da Inglatera), como o biálogo Patrick Geddes e, como seu imediato continuador, Lewis Mumford, promete um status cientifico às teorias urbanas.

En teras americanas, o sociologo Clarence Percy, na década de vinte deste século, atualiza a noção de crescimento celular, ao postular o principio da unidade de vizinhança como estrutura que se reproduz como partes com relativa autonomia, ascala das práticas cotidianas, acoplando-se a estruturas mais complexas e especializadas em uma totalidade urbana reconhecivel e controlaveil.

No plano das realizaçöes concretas, destacam-se as contribuiçōes, hoje clássicas, dos arquitetos Raymond Unwin, responsável pelo projeto des primeiras cidades-jardins inglesas; e dos norte-americanos Clarence Stein e Henry Wrigth, que praticam efetivamente o principio de unidade de vizinhança no urbanismo americano, com destaque ao projeto da cidade nova de Radburn, datado de 1929.

Vejamos como Lynch traduz as caracteristicas de um sistema vivo, na perspectiva de reconhecé-las ou ainda, aplicá-las - no desenho das cidades:

Um orgarismo $\dot{\theta}$ um individ to autonomo com fimites e tamanho definidos. Näo muda de tamanho sim. plesmente estendendo-se ou inchando-se, ( . .) mos sim que reorgarize sua forma zo mudar de tamanho (... ). Ainda que tentha um marcado limite axterior, näo ó tāo facil dividi-io internamente. IStras) partes estâo en estreito contato entre si de forma sutịl. A forma e a funçăo estăo indissoluvelmente ligadas, e 
a funçāo do todo é complexa, jó que năo pode ser compreendida somente pela naturaza das partes (...). Todo o organtsmo o dinámico, mas se trata de um dinamismo homeostático: os ajustes intemos tendem a fazer woltar o organismo a um esta do de equilibrio sempre que é perturbado por alguma força externa. Assim pois, é auto-regulador. Tambem se organiza a si mesmo. Se auto-repara, produz novos individuos e se submete a um ciclo de nascimento, crescimento, maturaçăo e morte. A aça nitmica e ciclica é nomal (...). Nossa observaçäo de tais entes esta acompanhada de sertimentos do assombro a afeto (p. 72$\}$ ?

Lynch segue conduzindo com rigor sua anälise, com o objetivo de confrontar tais caracteristicas frente às cidades existentes. De fato, encontra uma série de situaçōes em que a analogia cidade/organismo parece uma verdade vigorosa. Assinala ainda a imensa influência dessa abordagem no pensamento urbanístico e no planejamento urbano, fazendo notar que tal perspectiva permanece forte, associada agora aos movimentos ecológicos. As constantes, $e$ por vezes contundentes, criticas que tem como avo a teoria da cidade como forma orgânica, Lynch faz ver que "(...) näo surgiu oufra teoria de aceitaçāo geral que tornasse seu lugar. (..) Ainda que, finalmente, devamos criticar muitas das principais idélas desta teoria, há nela muitos elementos clarificadores" (p.76) .

A estrutura de utma cidade está indissociavelmente vinculada ao seu padräo de organizaçâo, como foi visto na seçäo 2. desté texto. Neste sentido, o padräo incorpora a essência das relaççes que fazerr de um conjunto de elementos uma estrutura. Isso è mais facilmente compreendido no âmbito das teorias que tratam da organizaçăo dos sistemas vivos. Os trabalhos de Maturana e Varela, Atlan e Prigogine, referências anteriormente mencionadas, apolam essa posiçăo. Fritjof Capra, a sua vez, ao sustentar que o padrāo de organizaçāo da vida é um padrăo em rede, considera que "(...) há trés tipos de sistemas whos - organismos, partes de organismos e comunidades de organismos - sendo todos eles totalidades integradas cujas propriedados essenciais surgem das interaçōes e da interdependência de suas partes (1996:44).

Sendo a cidade uma entidade social, è pertinente questionamos se essa afirmação, formulada inicialmente no dominio da biologia, possa ter validade no campo das teorias urbanas. A pergunta, então, se recoloca nos seguintes termos: é a cidade um sistema wivo?

Poder-se-ia alegar que essas são visöes formuladas por cientistas distantes da real problemática urbana. Mas, nas entrelinhas do discurso utbanistico, não é difícil encontrar apoio a esse ponto de vista. A cidade como sistema vivo comparece, em maior ou menor grau, no pensamento de Patrick Geddes (aliás, um biólogo), Lewis Mumford ou Jane Jacobs. Tambem no pensamento de Alexander e na obra recente de Pesci, a compreensăo da cidade como sistema vivo surge contundente, indo além da alusão metafórica.

Em 1961, ano da publicação de The death and life of great american cities, um dos livros mais importantes já escritos sobre a cidade moderna, Jacobs todavia colocava a questăo nos seguintes termos:

Embora o fato das ciencias da wida e as cidades sugerirem os mesmos tipos de problemas, jsso năo significa que sejam os mesmos problemas. As organizaçöes de protoplasma wivo e as orgarizaçoes de pessoas e empresas nāo poder ser exaninados sob os thesmos microscópios.

Porém, as táticas por entendếlos säo semellantes, no sentido em que ambos dependem de uma visáo microscófica ou detalhada, ou, dito de outro modo, algumas vezes, naqueles casos de menor detahe, a visao a olho nu e satisfatoria para wer os problemas de sirnplicidade; en outros, a visä́ telescopica remota è capaz de enxergar os problemas da complexidede desorganizada (1992:439\}'.

Năo é possivel perder de vista as limitaçōes concernentes à metäfora orgănica. Cidades năo se reproduzern ou contsertam-se por si mesmas, e mesmo a perspectiva sedutora de mecanismos homeostáticos, eventualménte presentes em sua auto-regulaçāo, nāo pode ser tomada literalmente. Por outro lado, a estabilidade dos limites, e a integridade reconhecivel das partes da cidade, estāo sujeitas a enormes variaçōes, ao longo da história, e em distintas culturas. A relativa autonomia da cidade, como um organismo em acoplamento com seu meio exterior é outra questäo provocadoramente controversa. Por agora, o que interessa mais diretamente ao ambito desta anàlise, é reconhecer a profunda impregnaçäo do pensamento sistêmico nas teorias urbanas, em grande parte devido à condiçäo de complexidade do fenomeno cidade.

\section{Itinerários abertos entre os possiveis}

Ao longo da seçåa 4., procurei visualizar analogias que dăo corpo a um exame térico dos processos de urbanizaçăo, descortinando a considerável presença das abordagens gerais normativas na formulaçăo do 
pensamento urbanístico. Ambas as metaforas, lingü/stice e cibernética, constituem, em um campo virtual de possibilidades '" trajetórias conceifluais que operam na atualizaçăo da complexidade inerente $\theta$ imanente ao objeto de conhecimento.

Neste sentido, quero melhor situar duas afimações, mencionadas na introdução, que no entanto exigerr alguma explicitaçăo. Desde a consideração de que a cidade é uma instituçäo social, e se tomo o ponto de vista de Maturana e Varela (1995:225-6), entåo esta constrój-se no domínio das condutas culturajs. Em decorrēncia, revendo as colocaçöes de Maraschin e Axt (1998:137), citadas na introduçāo, podemos agora caracterizar a cidade como i) uma tecnologia de inteligencia, em si mesma, e; ii) um sistema cognitivo que se realiza no acoplamento estrutural - isto e, na complementaridede estrutural necessária entre o sistema deteminado por sua estrutura e o meio (Maturana, 1999:86; Maturana, Varela, 1995: 113) - de uma multidäo de sujeitos, em uma rede multi-escala de lugares e coordenaçós semánticas.

Coordenar cidade e fexto em uma mesma perspectiva analitica parece um esforço mais consistente do que simplesmente apropriar-se "clandestinamente" de idéias e conceitos. A morfologia da cidade afirma-se como uma dimensäo essencial no fazer e compreender a cidade. Os caminhos dos habitantes de uma cidade conectam os mecanismos perceptivos ap ato de conhecer. Cada cidade, mesmo aquelas ern que a metáfora maquinistica é dominante (quando projetadas por urbanistas, entäo um texto acabado sobre o qual interagir), parece fazer ernergir um linguajar urbano-arquitetónico, definidor de um domínio particular de condutas culturais. Outra vez, o aforismo de Gerteau (1985), colocando lugar igual a língua, sugere uma relação estreita entre o espaço urbano e o dominio da linguagem.

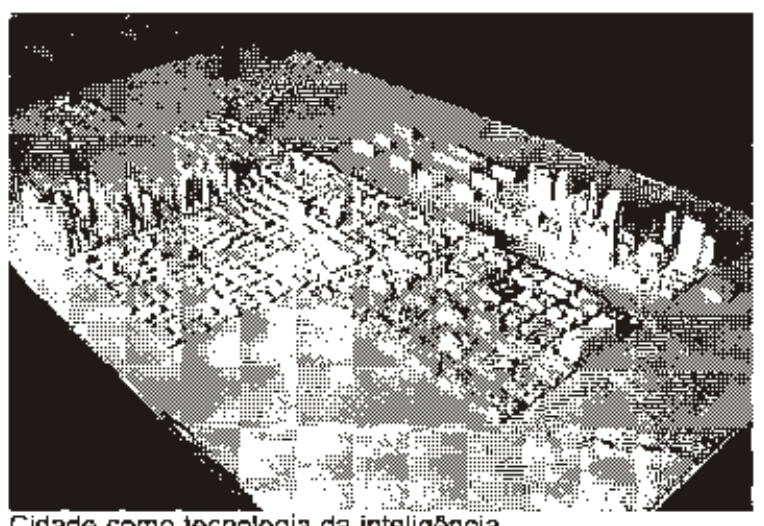

Cidade como tecnologia da inteligencia.

A Santa Fé, simulada atravess de múl|iplas coordenaçōes de saberes: espaço virtual que se estrutura pela interaçāo dos sujeitos da aprendzagem. Foto de Lisiane Bohn, 1999.
Tomando como exemplo nossa experiéncia recente, em parceria com o sociologo Eber Marulo, na aprendizagem de teorias urbanas, temos buscado explorar as possibilidades de construir conhecimento através da simulaçāo de uma cidade que é imaginada por um coletivo de sujeitos, a partir de um fragmento de 0 tempo e o vento, onde Érico Verissimo nama a fundação do powoado de Santa Fé (Andrade, Axt,1999b'1). Estamos, em considerâvel medida, objetivando operar um dominio de condutas culturais (urbanas) em um contexto virtual (de simulaçäo) como processo de construçāo cognitiva. Entendo que, nesta perspectiva, a cidade configura, em si mesma, uma tecnologia de inteligência onde, através de "acoplamentos virtuais" entre sujeito e objeto - e por extensả, sociedade e território - se constrói conhecimento. A cidade simulada - isto é, estabejecida através de operaçōes em um campo virtual de possiveis - é, neste sentido, uma sintese dialética do conhecimento estruturado dos sujeitos e das teorias trabalhadas no processo de aprendizagem.

Uma abordagem inversa, desde a cidade real à compreensāo de seu domfrio de condutas, parece uma considerável possibilidade teórica. Neste sentido, poder-se-ia pensar a cidade como operando-como tecnologia - na constituiçáo dos domínios da linguagem e da cultura.

Na perspectiva de uma investigaça futura, a possfvel abordagem da cidade como tecnologia de inteligência pode iniciar-se então, desde a hipótese de trabalho que considere a relaçăo de estreita conexảo entre o "espaço" da cidade e a evoluçăo das tecnologias da inteligência, desde os tempos anteriones à invençáo da escrita, até os dominios virtuais do ciberespaço. Neste mesmo ponto de vista, poder-se-á considerar uma coordenaçăo de efeitos mútuos, isto e, por exemplo, a evoluça das tecnologias da inteligéncia apoitando transformaçöes estruturais no espaço urbano, ao mesmo tempo em que o espaço, como lugar de interaçăo entre sujeitos cognitivos, realiza as condiçōes necessárias a essa evoluçăo.

Da mesma forma, interessa-me visualizar - relacionando ao momento anterior que examinou a triplice metafora da cidade como cosmo/máquina/organismo sob um mesmo prisma cibernético - a cidade como um sistema cognitwo complexo, que caracteriza-se pela condiça de estabelecer acesso social ao espaço da linguagem. Assim, na constante interaçāo entre sujeitos, e entre sujeitos e ambiente, a cidade, como locus de uma rede de coordenaçöes estruturais, se faz configurar como um complexo dom[nio lingüistipo, acessivel aos 
sujeitos que fazem parte desta mesma rede semåntica constituida através das condutas urbanas. Esta perspectiva poderia ser tomada como hipótese de trabakho para definir a condição de sistema cognifivo, que é propria a cidade, $\theta$ que na cidade realiza-se como totalidade.

Neste segundo esboço, há de se refletir quanto ao fechamento e a permeabilidade estrutural do sistema cidade, com relaçăo aos processos interativos na dialética comunidade/teritório. Cabe referir aqui, ao principio de auto-organizaçăo (dos sistemas cognitivos, no presente caso) cono mecanismo (cibernético, isto 6 , apto a controlar a informaçăo) capaz de operar sobre os sistemas urbanos. Na perspectiva da auto-regutação, o mecanismo permitiria pois, através de coordenaçōes continuadas, avaliar os avanços e recuos da comunidade e seu espaço, e indicar os padröes a conservar, adaptar ou inovar (Alexander, 1978:102) (2). $^{12}$.

Compreender a cidade como um sistema cognitivo, o que the confere qualidades auto-organizadoras e autopoiéticas, no entanto, nāo pressupōe a analogia literal com qualquer das metaforas examinadas, todas contidas e acopladas ao processo, ern rede, dos atos de conhecer. Antes, trata-se de interpretar a cidade como uma vasta rede cognítiva, redes dentro de redes, ecossistemas acoplados a ecossistemas ${ }^{13}$, na indissociavel relaçāo (criaçāo/sustentaçāo) entre redes "fractais" de sujeitos e lugares.

\section{Ao modo de finalização: a metáfora fractal}

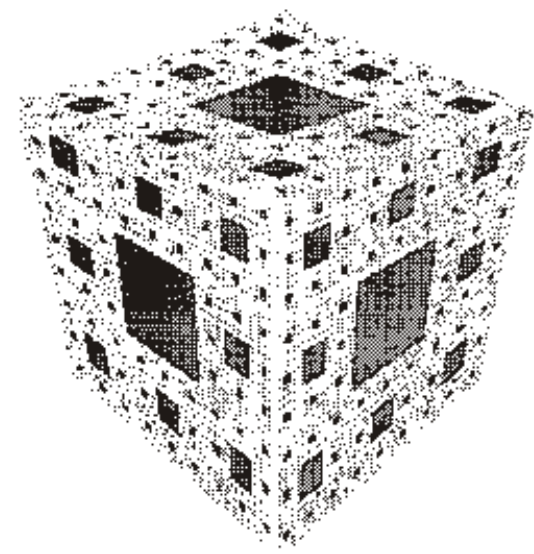

A metafora factal: a "exponja de Menger". Wustraçăo bo autor, 1999 , a partir de Gleick (1990). bin cronópio pequenininho procturava a chave da porta da rua ra mesaudecabeceira, a mesa-de-cabeceira no quarto de dormit, o quarto de dormir na casa, a casa na na. Por aqui parava o cronopto, pois para sair a rua precisava da chave da porta (Cortäzar: 1964:118\}).

A metárora fractal consolida a imagem da cidade como rede de ecossistemas - fisicos e cognitivos - em acoplamento estrutural. Neste sentido, quando se define a cidade como sistema cognitivo, o que se apresenta ê um mundo de posssibilidades dinâmicas, em constante rearranjo de formas a significados. Do mesmo modo, tomando a cidade como tecnologia da inteligencia, no sentido em que esta é um sistema aberto que pode incorporar e conter múltiplas tecnologias en si mesmas, constitujndo-se como uma rede de interfaces. O simpático personagen de Julio Cortázar nos mostra esse charo mundo, de que falam Maturana e Varela, atraves de atos coordenados de conhecer. através de interaçōes mais e mais complexas. O mundo do pequeno cronópio é um munoo de possiveis em constante devir.

Para Piaget $(1985,1995)$, a questão primordial da epistemologia construtivista está referida ao problema da "abertura para novos possiveis" (1985:7), conquanto significa a "... construção ou cração do que existia aperas en estado virtual do 'possivel' e que o sujeito devera atualizar" (Piaget,1995:52). O campo virtual das possibilidades (1985:136), todavia, nāo se circunscreve aos kimites do observavel, na medida em que gestado no contínuo movimento entre equilibrio e desequilibrio de estruturas cognitivas (1985:137) ou, em outras palavras, no balanço constante entre orden e desordem. Há pois que considerar que cada conjunto de possiveis abre, por definicaan, a perspectiva de determinar novas possibilidades, e de onde conclui-se que o conjunto de todos as possiveis é aberto (tendencialmente ilirnitado), "... nāa sendo o próprio 'todos' senäo um possivel em movimento (1985:8).

De outro modo, coloca Prigogine (1996:194), "(..) a inaginação dos possiveis, a especulação sobre o que poderia ter sido é um dos traços fundamentais da inteligencia humana." Eis entäo colocada uma das questōes essenciais, quando exploramos as relaçōes entre o espaço da cidade e do conhecimento. Se a açäo de construir a imagem guarda relaça com o dominio da linguegem, de quase inabarcável complexidade, săo as condiçöes derivadas deste dominio que poderảo definir a campo dos possiveis. A viagem clandestina das idèias, promovida por Morin, acontece neste virtualmente ilimitado conjunto de todos os possiveis: o espaço da linguagem permanece um sisterna aberto, longe do esgotamento e do equilibrio. Desde o ponto de vista de Maturana e Varela (1995): 
(...) A linguagem nunca foi irjentada por um sujeito isolado na apreensäo de um mundo extemo e. portanto, näo pode ser usada coma ferramenta para revelar tal mundo. Aa contrário, é dentro do linguajar mesmo que o ato de conhecer, na coordenaça comportamental que e a linguagem, produz um mundo. Realizamos a nós mesmos em mútuo acoplamento lingüistico, näo porque a linguagem nos permite dizer o que somos, mas porque somos na linguagem, num continuo existir nos mundos lingüísticos e seraanticos que produzimos com os outros, encontramos a nôs mesmos nesse acoplamento, não como a origem de uma reforencia, nem em referência a uma origem, mas sim em continua transformaça no

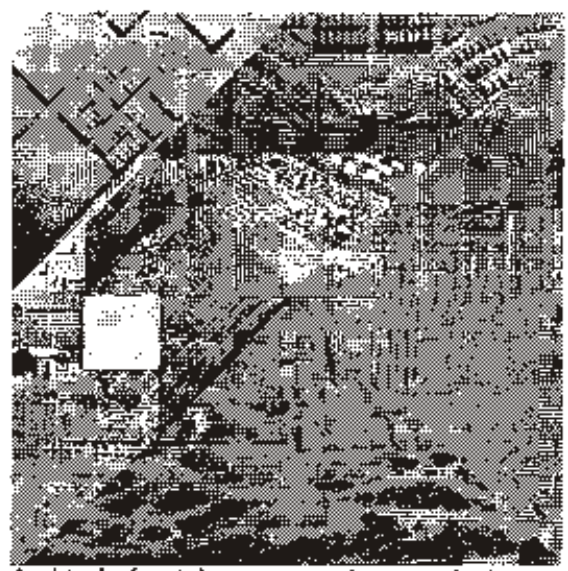

A cidade fractal: a campo dos possiveis Fotos de Lisiane Bahn \{1997/99\}. montagem de Carolina Cabrales (1999) wir-a-ser do mundo lingúistico que construimos com os outros seres humanos (p.252).

Tudo o que é dito, é dito por alguém. Tudo, na cidade, corresponde a atos e coordenaçōes entre sujeitos, e entre sujeitos e espaço, no linguajar do qual emerge a taxe urbana. Cidade e linguagem, no acoplamento profundo de seus elementos, produzem assim um "espaço" multidimensional, dentro do qual nos movemos e coppramos mutuamente, construindo o real a partir da interação atraves da linguagem, mas tambem, tal como sugere Certeau (1985), dos atos de fala de cada lugar. E nesta perspectiva que se pode observar a cidade como sistema cognifivo, pois que todos os seus elementos, físicose subjetivos, conectam-se na mesma rede fractal de sentidos, e como tecnologia de inteligéncia, quando as instituiçóes e processos sociais - a rede de coordenaçoses dai emergente - confomarm o locus instituinte do conhecimento humano.

\section{Notas do texto}

1 Extraido de Linguagem com tijolos [Andrade, 1999], a publicar. As nocōes trabalhadas ao longo desta seçăo såo tomadas especialmente deste texto.

- Vifalidade e sentido sào categorias tomadas de Lynch (1985)

3 Conforne depregnde-se das prefacios que, em separado, os autores elaborampara a rediçāo, vinte anos após a primeira wersáo, do [iwo De maquinas a seres vinds (ed. bras. 1997).

"A expressäo "artes do fazer" é tomada do titulo de uma importante obra de Michẹl de Certeau. Ver Gerleau, Giard, Mayol, 1996

s Rossi, A. (1979). My Designs and Analogous Archltecture. in: Aido Rossi is Amenica. New York, IAUS. Citado por Manfuz, $1995: 69$.

- Traduzido liwremente do texto em espanhol. Una máguina (...) tiene parfes pemanentes, pern estas pertes se muever y muever a las demás. La máquina entera puede cambiar, aduque to hace en forma claramente previsible, como si se moviera ininterampidamente por una piste delermirladta. La estabilidad es inherente a las partes y no al todo. Las partes son pequeñas, bien definidas, com

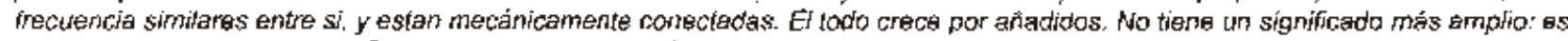
solo la suma de sus partes. Puede decomponerse, volver a constituitse invertirge. se pueder reernplazar las piezas $y$ valver a funcioner. Es fáctico, funcional, "frio", nada mágrco. Las partes son autonomas excepto por los asfabores que las hen sido prescritos. Hace solo to que hace y nada más (Lynch 198567 ).

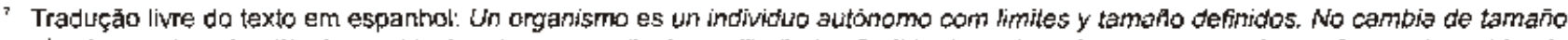

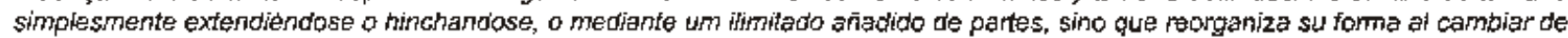
tamano (..). Aunque tiene un marcado limite exteror no es tan fajl diwdinto intemsmente. [Suas] partes estan en estrecho contecto

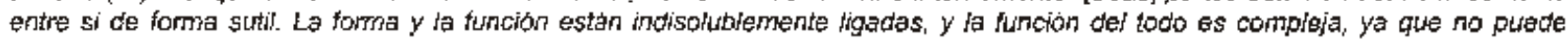
comprenderse solo por la haturaleza de las partes (...). Todo ef ongrismo es dinamico pero se trata do un dinamismo homeostatico: los ajustes intemos tierden a hacer volver al organismo a un eslado de equilibrio siempre que es pertumado por alguna fuerza extema. Asi pues, es automgulador. Tambien se organiza a si mesno. Se automepara, praduce nuevos individus $y$ se somete a un ciclo de nacimiento. crecimiento, madurez y muerte. Le accion ritmica y cicliea es nombl (...). Nuestra observacion de tales entes esté acompañada de sentimientos de asombro y afocto (Lynch, 1985:72)

a Traduça livire do texto em espanhol: (...) no ha surgido otra teoria de aceptación general que la reamplazara. (...) Aunque finalmente debemos eriticar muchas de las principales ideas de esta teoria, hay en ella muchos elementos clanticadores (Lyneh, 1985:76).

3 Traduzido livremente do original en ingless: Because the life science and cilies happen to pose the same ikinds of problems does not mean they are the same probiems. The organizations of living protoplasm and the organizations of living paople and enterprises cemel go under the same microscopes.

However, the tactics for underslanding both are simitar in the sense thet both depend on the microscopic or deteiled view, so to speak,

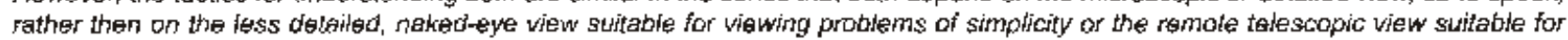
viewing problens of disorganized compliaxity (Jacobs, 1992.439).

10 Sobre o problema dos posziveis, torhando o sentido proposto por Piagel, tratäros inicialmente em ANDRADE, L. W. W, AXT, M. (1999a).

"1 Faço aqui referéncia a expertência pedagogloa que empneendemos, ao longo dos ültimos tres anos, na disciplina A.FQ 02.001 Tearjas sobre o Espaço Ubano do curso de graduaça em Arquitetura e Urbarismo da UFRGS. A axperiencia está daserita, com considera-

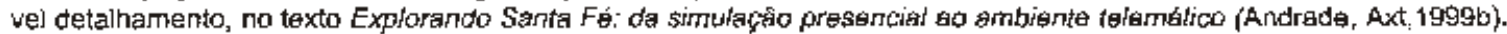


cabe aqui uma mençá brewe, outra wez fazendo referéncia ao experimento de simulaçāo urbaria. Quanso exploralmos - alnda que de

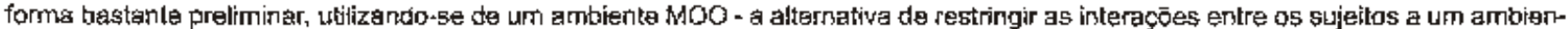
te configurad no ciberespayo, vhímbramos a emergencia da condiça auto-organizadora. Libertos das restricoes do espaç evdidiano

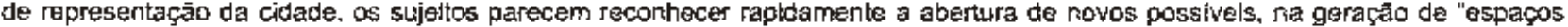
urbanos" inovadores.

1.) Como coloca, en siritese, Capra (1996).

\section{Referèncias bibliográficas}

ALEXANDER, C. (197B). Urbanismo y participación. Barcelona, Gustavo Gili

(FBT). El modo intemporal de construir. Barcelona, Gustavo Gili.

(1997) Notes on the syathesis of form. Cambridge, Harvard Uniwersity Press.

ALEXANDER, 0 , et al. (1982). A pattem language/un lenguage de patrones; ciudades, edificios, construceion. Barcelona, Gustavo Gili.

ALEXANDER, C., NEIS, H., ANNANOU, A., KING, I. (1987). A new theory of urban design. New York, Oxford Uniwarsity Press.

ANDRADE, L. M. V. (1993). A Estrutura de áreas residenciais e a ideologia projetuai: dois paradigmas em discussảo. Porto Alegre, PROPUR/UFRGS. Dissertaça de Mestrado, CASTELLO, L. (or.).

(1998). O arquiteto no quarto chinés? a aprendizagem da arquitetura como conhecimento por simulaçāo. Projeto de pesquisa apresentado ao PGIE-UFRGS como proposta de ingresso no Curso de Doutorado em Informática na Educacăo (mimeo)

ANDRADE, L. N. W. (1999). Linguagem com tijolos. hi: Aprendendo de Santa Fé: contribuça ao estudo das teorias unbanas. Poto Alegre, DeUrbiluFRGS (a pubticar).

ANDRADE, L. M. W., AXT, M. (1999a). A construçāo dos possivejs em arquitetura: epistemalogia genftica e ecologia cognitiva. In: Informática ria Educaça: teoria e prática. Porto Alegre, PPGIEIUFFGS. v2.n.2. pp 39-44

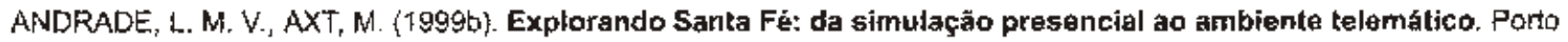
Alegre, PPGIEUFRGS.

ASHEY, W. R. (1970). Intraduçăo á cibernética. São Paulo, Perspectiwa.

ATLAN. H. (1992). Entre o crlstal e a fumaça: ensaio sobre a organização do vivo. Rio de janeiro, Jorge Zahar Editores.

AXT, M. (1998a). Conhecimento sócio-cognitivo e autopoiese na rede talemática. (mimeo).

(1998b). Estudos cognitivos: mapeando tendencias (mimeo\}.

AXT. M. MARASCHIN, C. (1996). Prática pedagógica pensada na indissockabilidade conhecimento-subjetividade.

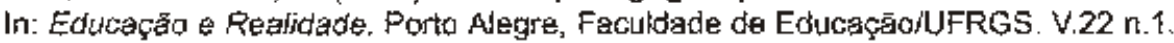

(1998). Conhecimento. In: JACQUES, M. G. C. ET AL. Psicologia Social contemporanea. Petrópalis, Vozes.

BERTALANFFY, L. V. (1977). Teoria geral dos sistemas. Petropolis, Vozes.

BRAUDEL, F. \{1991\}. Escritos sobre Historia. Ciudad de Mexico, Fondo de Cutura Economica.

CALVINO, $\$$ (1991). As cidades invisiveís. Sāo Paulo, Cia das Letras.

GALVINO, Ł. (1992). As cosmicômicas. Săo Paulo, Cia das Letras.

CAPRA, F. (1996). A teia da vida. Säo Paulo, Cultrix.

CARR, S. (1967). The city of the mind. 却iana, Indiana University Press.

CASTELLO, L. et al. (1986), Investigação de diretrizes para um projeto ambiental. Porto Alegre, PROFUR-UFRGSi ROSTLAC-UNESCO.

CERASI, M. (1977). La tectura det ambiente. Buenos Aires, Editorial tnfinito.

CERTEAV, M de (1985). Teoria e método no estudo das práticas cotidianas. In: SMRECSANY, M. (Org.) Cotidiano, cultura popular e planejamento urbano. São Paulo, FAL-USP.

CERTEAU, M de, LUCE, G., MAYOL, P. [1996). A invençăo do cotidiano: morar, cozinhar. Petrópolis, Vozes.

CORTAZAR, 4. (1964). Históñas de Cronópios e Famas. Sāo Paulo, Circuto do Livro.

CHOAY, F. (1979). Urbanismo; utopias a reatidades. Petrópolis, Vozes.

ECO, U. (1976). A estrutura ausente. Säo Pauta, Perspectiva, 
HERTZBERGER, H. (1996). Liçōes de arquitetura, Säo Paulo, Martịs Fontes.

JACOBS, J. (1992). The death and life of great american clties. New York, Vintage Books.

LYNCH, K. (1985). La buena forma de la ciudad. Barcelona, Gustavo Gili.

KRIER, R. (1981). El espacio urbano. Barcelona, Gustavo Gili.

LEĂO. Lúcia. O labirinto da hipernidia: arquitetura e navegaçāo no ciberespaço. Sāo Paulo. Fapesp/llúminuras.

LEITE, L, B. (1995). Plaget e a escola de genebra. Sáo Paulo. Cortez.

LEW, P. (1993). As tecnologias da inteligéncia. Săo Paulo, Editora 34. [1999\}. Cibercultura. Sào Paulo, Edifora 34.

LUHMANN, N. (1997). A nova teorla dos sistemas. Porto Alegre, Editora da Universidade.

LYNCH, K. (1985). La buena forma de la ciudad. Barcelona, Gustavo Gili.

MAHFUZ, E. C. (1995). Ensaio sobre a razão compositlva. Viçosa. UFVAP Cultural.

MATURANA, H. R., WARELA, F. J. G. (1995). A árvore do conhecimento: as bases biológicas do entendimento humano. Campinas, Editorial Psy.

MATURANA, H. R., VARELA, F. J. G. (1997). De máquinas e seres vivos - autopoiese: a organizaçào do vivo. Porto Alegre, Artes Médicas.

MATURANA, H. R. \{1999\}. Ontologia do conhecer. Porto Alegre, Artes Médicas.

MORIN, E. (1991). Introduçāo ao pensamento complexo. Lisboa, Instituto Piaget.

PESCl, R. (1985). La Ciudad In-Urbana. La Plata, Editorial A/mbiente. - (1985). La Ciudad de la Urbanidad. La Plata, CEPA, Euenos Aires CP67.

PIAGET, J. (1985). O possivel e necessário. Porto Alegre, Artes Médicas, Volume 1.

. (1995). O possível, o impossivel e a necessário. In. LEITE (org.). Piaget o a escola de Genebra. Săo Paulo, Cortez, pp. 51-71.

PRIGOGINE, I. (1996a). O fim das certezas: tempo, caos e as feis da natureza. Sao Paulo, Editora UNESP.

(1996b). O firn da ciência? In: SCHNITMAN, D. (org.). Nowos paradigmas, cultura e subjetividade. Porto Alegre, Artes Medicas.

- (19960). Dos relógios às nuvens. In: SCHNITMAN, D. (org.). Novos paradigmas, cultura e subjetividade. Porto Alegre, Artes Médicas.

PRIGOGINE, I., STENGERS, I. (1984). A nova aliança: metamorfose da ciência. Brasidia, Editora da UmB.

ROWE, C, KOETTER, F. (1981). Collage city / Ciudad collage. Barcelona, Gustavo Gili.

SPIRN, A. W. (1995). 0 jardim de granito. Säo Paulo, Edusp.

STROETER, J. R. (1986). Arquitetura e teorias. Säo Paulo, Nobel. 